Volume 1, Number 2, 2015

\title{
Gas-dynamic Analyzer of Nitrogen-hydrogen Mixture for Industrial Application
}

\author{
Halyna Matiko*, Yevhen Pistun \\ Lviv Polytechnic National University, 12, S. Bandera St., Lviv, 79013, Ukraine
}

Received: April 20, 2015. Revised: May 07, 2015. Accepted: October 22, 2015.

(c) 2015 The Authors. Published by Lviv Polytechnic National University.

\begin{abstract}
Mathematical model of gas-dynamic analyzer of nitrogen-hydrogen mixture built on bridge throttle scheme using laminar-turbulent and turbulent-laminar throttle dividers is developed in the paper. The developed analyzer has twice higher sensitivity than any of these dividers. The authors developed the algorithms for calculation the constructive parameters of gas-dynamic analyzer of nitrogen-hydrogen mixture to provide optimal sensitivity of the throttle bridge scheme. The types of throttle elements have been selected, their dimensions have been calculated, technical means for realization of gas analyzer scheme have been proposed. The authors developed a principal scheme of the gas analyzer of nitrogen-hydrogen mixture and calculated its static characteristic. The influence of uninformative parameters such as temperature and pressure of nitrogen-hydrogen mixture on output signal of analyzer is analyzed and measures for their stabilization are proposed. The authors also proposed tasks for the experimental investigation of the developed gas-dynamic analyzer.
\end{abstract}

Keywords: gas-dynamic analyzer; nitrogen-hydrogen mixture; bridge throttle scheme; throttle divider; throttle; sensitivity.

\section{Definition of the problem to be solved}

Ammonia is one of the most important products of modern chemical industry. Its annual global production reaches 100 million tons. Mainly ammonia is used for the production of nitrogen fertilizers (nitrate and ammonium sulphate, urea), nitric acid, soda and other chemical products. The main raw material of nitric industry is natural gas and coke gas. So the companies producing ammonia are placed in the mining areas of natural gas, along the lines of gas pipelines and in the areas of mining and coking of coal [1].

One of the main conditions for improving the efficiency of ammonia production is to obtain reliable information on the composition of gas mixtures. Particularly, the amount of ammonia significantly depends on the composition of nitrogen-hydrogen mixture that circulates in the apparatus for synthesis of ammonia. So gas analysis equipment of high precision should be used in order to provide qualitative analysis of this mixture.

Thousands of gas analyzers of about 400 types and hundreds of chromatographs are used in Ukraine. Often existing devices do not meet the requirements for the accuracy and sensitivity of measurement that are specified by technological process. Gas-dynamic throttle analyzers [2,3] can solve this problem of control since they have high sensitivity, reliability, ease of constructive implementation, low costs for production and operation, a wide range of applications.

\section{Analysis of the recent publications and research works on the problem}

The problems of constructing, modeling and designing gas-dynamic throttling devices are analyzed in a number of publications and research works [2-7]. New approaches to the design and construction of gas-

* Corresponding author. Email address: halynamatiko@gmail.com 
dynamic throttle measuring transducers using set-theoretic concepts [2] have been considered, the mathematical models and schemes of measuring transducers built on two, three or more elements have been presented [3,4] mathematical model of gas-dynamic analyzer of gas mixtures built on bridge scheme has been synthesized and its functionality has been analyzed [5-7].

\section{Formulation of the goal of the paper}

The goal of this paper is to synthesize mathematical model and principal scheme of gas-dynamic analyzer of nitrogen-hydrogen mixture containing $25 \% \mathrm{~N}_{2}$ and $75 \% \mathrm{H}_{2}$ to be applied in production of ammonia from coke gas. The influence of uninformative parameters on output signal of analyzer should be analyzed and measures for their stabilization should be proposed.

\section{Presentation and discussion of the research results}

One of the methods for obtaining nitrogen-hydrogen mixture for the production of ammonia is a method of deep cooling of coke oven gas. Nitrogen-hydrogen mixture containing $25 \% \mathrm{~N}_{2}$ and $75 \% \mathrm{H}_{2}$ is obtained using this method. According to the ammonia production technology requirements, we should develop gasdynamic analyzer of nitrogen-hydrogen mixture with measuring range $0-30 \%$ vol. $\mathrm{N}_{2}$ in $\mathrm{H}_{2}$ in order to provide qualitative analysis of this mixture. Initial data for calculation of the constructive parameters of analyzer are the physical parameters of the nitrogen-hydrogen mixture, namely $\rho, \mu \mathrm{i} \chi-$ density, dynamic viscosity and isentropic exponent of gas mixture, temperature $T$ of gas mixture and supply pressure of transducer $P_{\text {in } p}$ and $P_{\text {out }}$ whose values are grounded below.

Pressure of the analyzed mixture $P_{i n p}$ at the input of throttle scheme of analyzer is selected from the conditions for the normal flowing modes of throttles in the scheme and within the operating range of absolute pressure regulators. Therefore we choose the input pressure $P_{i n p}=200 \mathrm{kPa}$. Pressure of gas mixture $P_{\text {out }}$ at the output of throttle scheme of analyzer must not exceed the maximum value of barometric pressure. As this pressure does not exceed usually $106.6 \mathrm{kPa}$ we take $P_{\text {out }}=110 \mathrm{kPa}$. The temperature $T$ of nitrogen-hydrogen mixture and analyzer we determine taking into account the range of changes of ambient temperature and temperature of gas mixture sample. To ensure the normal operation of the stabilization system of temperature of nitrogen-hydrogen mixture and transducer elements at measuring conditions we choose $T=313 \mathrm{~K}$. Physical parameters of nitrogen-hydrogen mixture (density, dynamic viscosity and isentropic exponent) for working conditions of gas-dynamic analyzer were calculated using Computer Aided Design of Differential Pressure Flow Meters (CAD "Raskhod -RU") [8].

Synthesis and design of gas-dynamic devices is based on structural optimization (choice of scheme and type of throttle elements) and parametric optimization (choice of throttles parameters) [2]. Therefore we analyzed existing schemes of analyzers such as scheme built on two throttle elements and throttle bridge scheme in order to select the optimal scheme. We chose the optimization criterion - averaged sensitivity $S_{D}$. This is the sensitivity at the measuring range, which is defined as the ratio of increase of changes of output signal $X_{\text {out }}$ to the increase of changes of the input signal $X_{\text {inp }}$ of analyzer [9]:

$$
S_{D}=\frac{X_{\text {out } 2}-X_{\text {out } 1}}{X_{\text {inp } 2}-X_{\text {inp } 1}},
$$

where $X_{\text {inpl } 1}, X_{\text {out } 1}$ are input and output values of the analyzer at the beginning of measuring range; $X_{\text {inp } 2}, X_{\text {out } 2}$ are input and output values of the analyzer at the end of measuring range.

Averaged sensitivity $S_{D}$ significantly depends on the scheme (structure) of gas-dynamic analyzer and the parameters of throttles. Thus, the problem of optimization of gas dynamic analyzer of nitrogen-hydrogen mixture is to choose throttle scheme and such parameters of throttles that provide maximum average sensitivity $S_{D}$ of scheme taking into account the limitations of supply pressure of analyzer, of characteristics of throttle elements and of motion mode (laminar or turbulent) of mixture in the throttle channels. 
In order to simplify the analytical solution of optimization problem, we used complex values $B_{A}, B_{B}$ and $B_{P}$, introduced in [5,6], as variables instead of individual parameters of throttles and mixture:

$$
B_{A}=\frac{d_{2}^{4}}{\alpha_{1} \cdot l_{2} \cdot d_{1}^{2}} ; \quad B_{B}=\frac{d_{3}^{4}}{\alpha_{4} \cdot l_{3} \cdot d_{4}^{2}} ; \quad B_{P}=\frac{\mu^{2}}{\rho},
$$

where $d_{i}, l_{i}$ are diameter and length of $i$-th throttle; $\alpha_{i}$ is flow-rate coefficient of $i$-th turbulent throttle; $\rho, \mu$ are the density and the viscosity of the analyzed gas mixture.

Thus, we formalized the parametric optimization problem of gas-dynamic analyzer of nitrogen-hydrogen mixture for specified optimality criterion:

$$
\left\{\begin{array}{l}
S_{D}=f\left(P_{\text {inp }}, P_{\text {out }}, Q, B_{P}, B_{A}, B_{B}\right) \\
B_{A}, B_{B} ; \\
P_{\text {inp }} \leq P_{\text {inp.up }} ; \quad P_{\text {out }} \geq P_{\text {out. } .} ; \quad Q \leq Q_{\text {up }} \\
d_{\text {i.up }} \leq d_{i} \leq d_{i . l} ; \quad l_{\text {i.up }} \leq l_{i} \leq l_{i . l} ; \\
Q_{i} /\left(\pi d_{i} \mu\right)<\operatorname{Re}_{\text {lam.up }} ; \quad 4 Q_{i} /\left(\pi d_{i} \mu\right)>R e_{\text {turb.l }} .
\end{array}\right.
$$

where $Q$ is mass flowrate of mixture through the scheme; $P_{i n p}$ i $P_{\text {out }}$ are the absolute pressure at the input and at the output of throttle scheme; $B_{A}, B_{B}$ i $B_{P}$ are the constructive and the parametrical complex values that depends on the type of throttle and parameters of gas mixture and are determined by the formulas (2). Indexes "l" and "up" mean the lower and the upper boundary of limitations.

We have analyzed throttle scheme that consists of a serial connection of turbulent and laminar throttles (T-L divider) (see Fig. 1, a) and throttle scheme that consists of a serial connection of laminar and turbulent throttle (L-T divider) (see Fig.1, b).
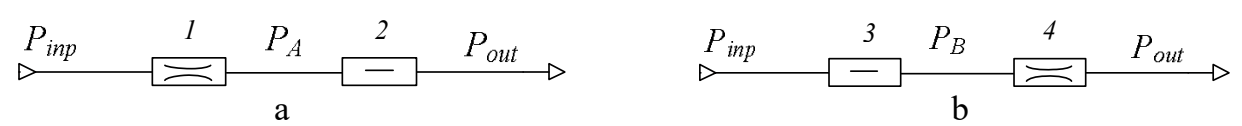

Fig. 1. Schemes of throttle dividers: $\mathrm{a}$ - turbulent-laminar divider; $\mathrm{b}$ - laminar-turbulent divider 1,4 - turbulent throttles; 2, 3 - laminar throttles

Calculation of parameters of the gas-dynamic analyzers built on two throttles with optimal sensitivity was made by the analysis of mathematical models described in $[4,5]$ and by solving them using the method of half division.

Figure 2 shows a diagram of the sensitivity changes of T-L divider and L-T divider depending on the constructive complex values $B_{A}$ and $B_{B}$. We calculated the maximum sensitivity of $\mathrm{T}-\mathrm{L}$ divider $S_{D}=-231 \frac{\mathrm{Pa}}{\% \mathrm{vol} . \mathrm{N}_{2}}$, that corresponds to the maximum change of output signal of analyzer - pressure between throttles $\Delta P=6.916 \mathrm{kPa}$ at the optimum constructive complex value of T-L divider $B_{A}=4.632 \cdot 10^{-6} \mathrm{~m}$, and also - the maximum sensitivity of L-T divider $S_{D}=258 \frac{\mathrm{Pa}}{\% \mathrm{vol} . \mathrm{N}_{2}}$, that corresponds to the maximum change of output signal of analyzer $\Delta P=7.742 \mathrm{kPa}$ at the optimum constructive complex value of L-T divider $B_{B}=2.93 \cdot 10^{-6} \mathrm{~m}$. 


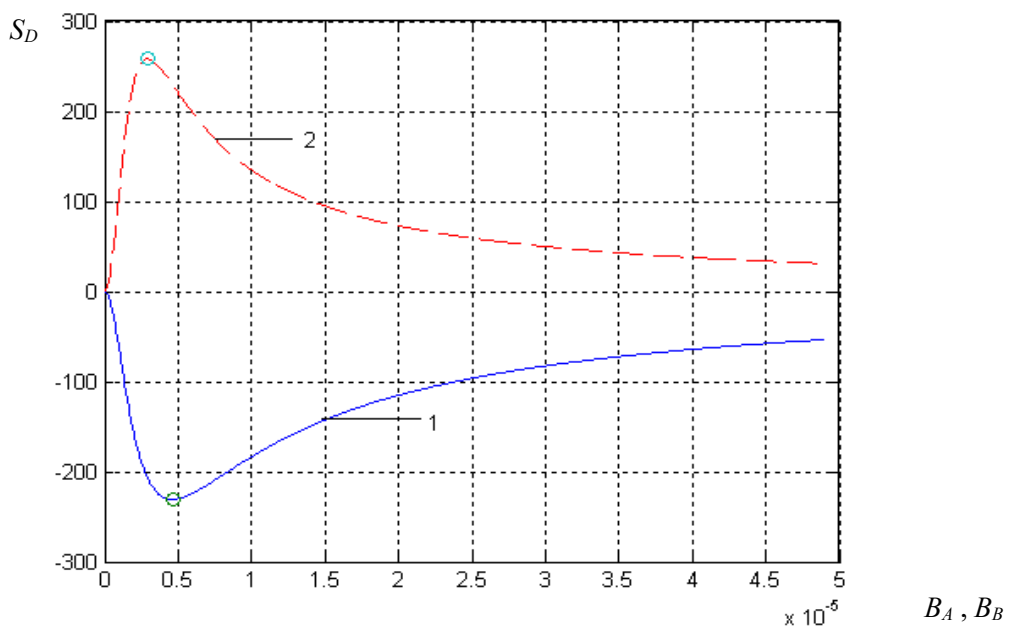

Fig. 2. Diagram of sensitivity changes

of T-L divider (curve 1) and T-L divider (curve 2)

The sensitivities of the dividers differ little between themselves and laminar-turbulent divider provides a little higher sensitivity. It should be noted that the sensitivities $S_{D}$ of the dividers have different signs. This means that the change in the composition of the nitrogen-hydrogen mixture leads to the change in pressures between throttles of L-T and T-L dividers in opposite directions. This feature can be used in the analyzers built on the bridge scheme based on these dividers. This allows increasing the sensitivity of measurement and provides zero output of the bridge scheme at the beginning of the measurement range.

Bridge throttle scheme of gas-dynamic analyzer built on the opposite included laminar and turbulent throttles and with differential manometer in output diagonal is shown in Fig. 3.

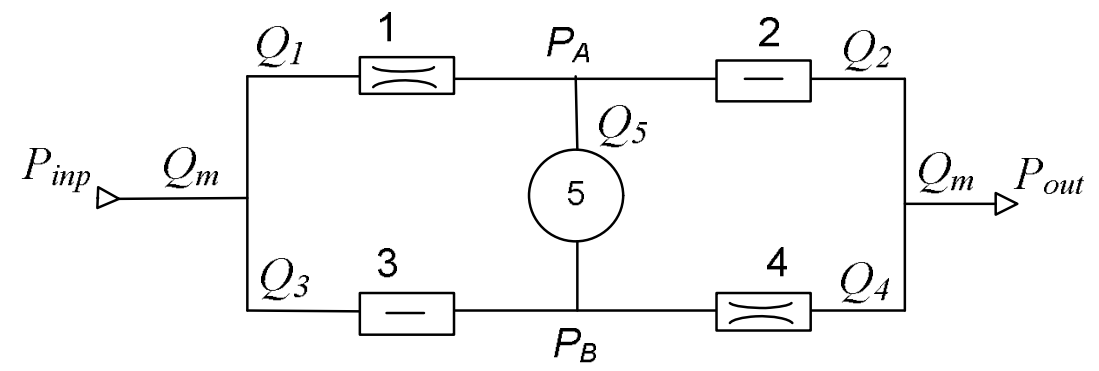

Fig. 3. Bridge throttle scheme:

1,4 - turbulent throttles; 2, 3 - laminar throttles;

5 - measuring device

Throttle dividers in scheme (see Fig. 3) have a common supply: input pressure $P_{i n p}$ and output pressure $P_{\text {out }}$. Mass flowrate of mixture through the throttles $1,2,3$ i 4 and also through the measuring device 5 are marked $Q_{1}, Q_{2}, Q_{3}, Q_{4}$ and $Q_{5}$, and the total mass flowrate through the bridge scheme - $Q_{m}$. When measuring device 5 is the differential manometer with hydraulic resistance $R_{5}=\infty$ the flowrate is $Q_{5}=0$.

Since we realize the measuring transducer of nitrogen-hydrogen mixture on the basis of the proposed bridge scheme in which we stabilize absolute pressures $P_{\text {inp }}, P_{\text {out }}$ and temperature $T$ of gas mixture, the model of such analyzer consists of the model of bridge scheme [5], and equations for determining parameters of gas mixture: 


$$
\left\{\begin{array}{l}
\Delta P=P_{A}-P_{B} ; \\
\left(\frac{T_{n}}{P_{n} \cdot T}\right)^{0.5} \cdot \frac{B_{A}}{64 \cdot \sqrt{B_{P}}} \cdot\left(P_{A}^{2}-P_{\text {out }}^{2}\right)=P_{\text {inp }} \cdot\left(\frac{2 \cdot \chi}{\chi-1} \cdot\left[\left(\frac{P_{A}}{P_{\text {inp }}}\right)^{\frac{2}{\chi}}-\left(\frac{P_{A}}{P_{\text {inp }}}\right)^{\frac{\chi+1}{\chi}}\right]\right)^{0.5} ; \\
\left(\frac{T_{n}}{P_{n} \cdot T}\right)^{0.5} \cdot \frac{B_{B}}{64 \cdot \sqrt{B_{P}}} \cdot\left(P_{\text {inp }}^{2}-P_{B}^{2}\right)=P_{B} \cdot\left(\frac{2 \cdot \chi}{\chi-1} \cdot\left[\left(\frac{P_{\text {out }}}{P_{B}}\right)^{\frac{2}{\chi}}-\left(\frac{P_{\text {out }}}{P_{B}}\right)^{\frac{\chi+1}{\chi}}\right]\right)^{0.5} ; \\
B_{A}=\frac{d_{2}^{4}}{\alpha_{1} \cdot l_{2} \cdot d_{1}^{2}} ; \\
B_{B}=\frac{d_{3}^{4}}{\alpha_{4} \cdot l_{3} \cdot d_{4}^{2}} ; \\
B_{P}=\frac{\mu^{2}}{\rho} ; \\
\rho_{n}=\rho_{n N_{2}} \cdot C_{N_{2}}+\rho_{n_{H}}\left(1-C_{N_{2}}\right) ; \\
\chi=\chi_{N_{2}} \cdot C_{N_{2}}+\chi_{z}\left(1-C_{N_{2}}\right) ; \\
\mu=\mu_{N_{2}} /\left[1+\varphi_{12} \cdot\left(1-C_{N_{2}}\right) / C_{N_{2}}\right]+\mu_{H_{2}} /\left[1+\varphi_{21} \cdot C_{N_{2}} /\left(1-C_{N_{2}}\right)\right] \\
\varphi_{12}=\left[1+\left(\mu_{N_{2}} / \mu_{H_{2}}\right)^{0.5} \cdot\left(M_{H_{2}} / M_{N_{2}}\right)^{0.25}\right]^{2} /\left[2 \cdot \sqrt{2} \cdot\left(1+M_{N_{2}} / M_{H_{2}}\right)^{p .5}\right] \\
\varphi_{21}=\left[1+\left(\mu_{H_{2}} / \mu_{N_{2}}\right)^{0.5} \cdot\left(M_{N_{2}} / M_{H_{2}}\right)^{0.25}\right]^{2} /\left[2 \cdot \sqrt{2} \cdot\left(1+M_{H_{2}} / M_{N_{2}}\right)^{0.5}\right]
\end{array}\right.
$$

where $P_{A}$ is pressure between throttles of T-L divider of bridge scheme; $P_{B}$ is pressure between throttles of L-T divider of bridge scheme; $T_{n}, P_{n}, \rho_{n}$ are temperature, pressure and density of nitrogen-hydrogen mixture under normal conditions; $M, \rho, \mu$ i $\chi$ are molecular weight, density, viscosity and isentropic exponent of nitrogen-hydrogen mixture at temperature $T ; C_{N_{2}}$ is concentration of nitrogen in mixture. Indexes of throttle parameters mean: 1, 2 - turbulent and laminar throttle of T-L divider; 3, 4 - laminar and turbulent throttle of L-T divider.

System (3) connects the output signal $\Delta P$ of gas-dynamic analyzer with throttle parameters that form the complex values $B_{A}, B_{B}$, with parameters of the mixture $\mu, \rho$ i $\chi$ that form the complex $B_{P}$ and therefore with the input signal - the concentration of nitrogen $C_{N_{2}}$. If throttle parameters and characteristics of gas mixture are known, we can calculate static characteristic of gas-dynamic analyzer of nitrogen-hydrogen mixture using the proposed model. The maximum sensitivity of scheme can be achieved if throttle parameters provide conditions $B_{A}=B_{A o p t}$ and $B_{B}=B_{B o p t}$. Therefore, we must find such pair of values $B_{A}$ and $B_{B}$ that provide maximum measuring sensitivity $S_{D}$ and balance of bridge scheme at the beginning of the measuring range (zero output of the bridge scheme at the beginning of the measuring range).

Using approaches to modeling of gas dynamic devices proposed in [10] the authors developed the algorithms for calculating the constructive parameters of gas-dynamic analyzer of nitrogen-hydrogen mixture to provide optimal sensitivity of the bridge throttle scheme. To implement these algorithms, we developed programs in Matlab, the results of which are presented below. Physical parameters of nitrogen-hydrogen mixture for working conditions of the analyzer were calculated using Computer Aided Design "Raskhod-RU” [8].

We calculated the optimal constructive parameter $B_{B o p t}$ for L-T divider of bridge throttle scheme of gasdynamic analyzer of nitrogen-hydrogen mixture. Thus, figure 4 shows the diagram of pressure $P_{B}$ between throttles via parameter $B_{B}$ for L-T divider of bridge scheme. The studied interval of change of parameter $B_{B}$ 
contains the maximum pressure $P_{B}$ between throttles that points the optimal constructive parameter $B_{B o p t}^{L T}=2.93 \cdot 10^{-6} \mathrm{~m}$ for L-T divider. It was mentioned above that the value of constructive parameters of throttle dividers should deviate from their optimal values in order to balance bridge throttle scheme at the beginning of the measuring range. We calculated the optimal constructive parameter $B_{B o p t}=3.8177 \cdot 10^{-6} \mathrm{~m}$ for bridge throttle scheme using the designed algorithms.

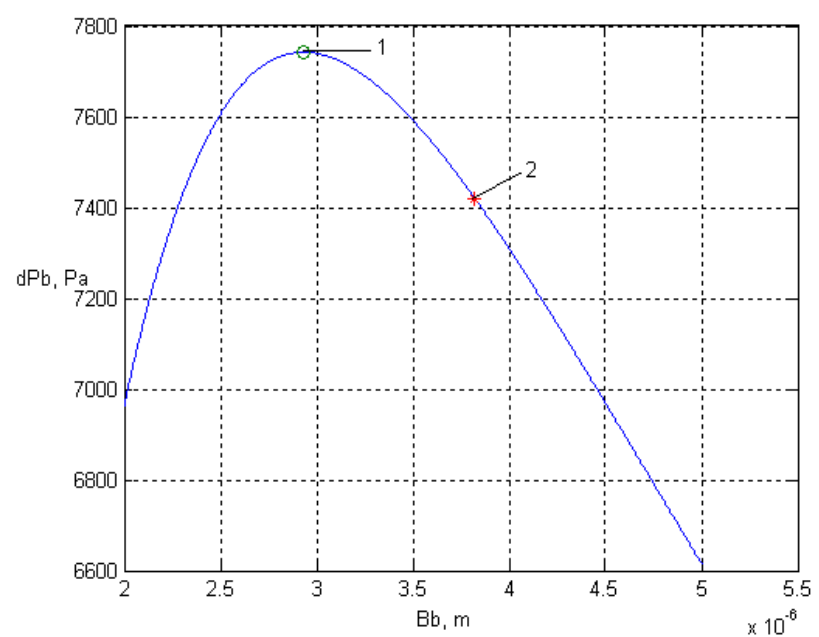

Fig. 4. Pressure $P_{B}$ between throttles via parameter $B_{B}$

$$
\begin{aligned}
1-\text { for L-T divider } B_{B o p t}^{L T} & =2.93 \cdot 10^{-6} \mathrm{~m} ; \\
2 \text { - for bridge scheme } B_{\text {Bopt }} & =3.8177 \cdot 10^{-6} \mathrm{~m}
\end{aligned}
$$

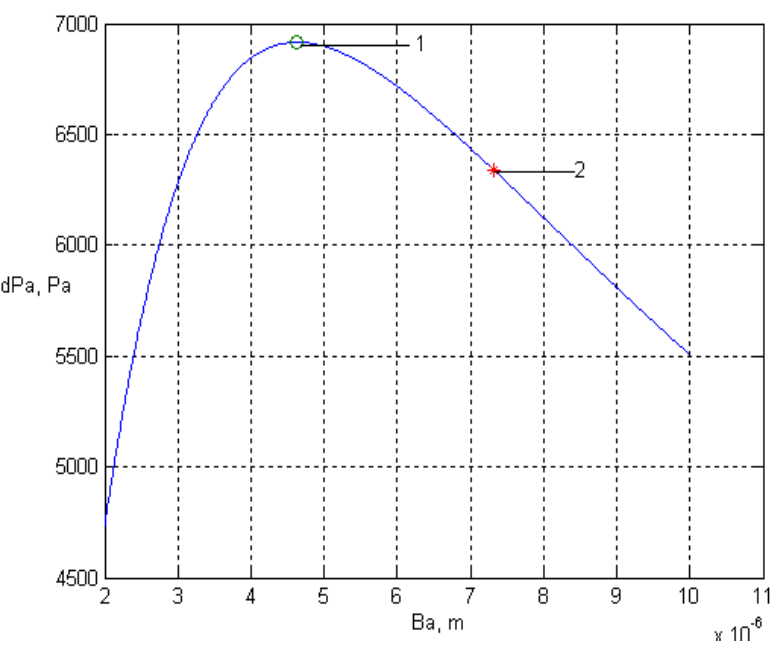

Fig. 5. Pressure $\mathrm{P}_{\mathrm{A}}$ between throttles via parameter $\mathrm{B}_{\mathrm{A}}$ 1 - for T-L divider $B_{\text {Aopt }}^{T L}=4.632 \cdot 10^{-6} \mathrm{~m}$; 2 - for bridge scheme $B_{\text {Aopt }}=7.3112 \cdot 10^{-6} \mathrm{~m}$

We also calculated the optimal value of constructive parameter $B_{\text {Aopt }}$ for T-L divider of bridge throttle scheme of gas-dynamic analyzer of nitrogen-hydrogen mixture. Figure 5 shows that the studied interval of change of parameter $B_{A}$ contains the maximum pressure $P_{A}$ between throttles that points the optimal constructive parameter $B_{\text {Aopt }}=7.3112 \cdot 10^{-6} \mathrm{~m}$ for T-L divider. We also calculated the optimal constructive parameter $B_{\text {Aopt }}=3.8177 \cdot 10^{-6} \mathrm{~m}$ for bridge throttle scheme in order to balance the scheme at the beginning of the measuring range.

Using the developed algorithms we calculated the output signal of gas-dynamic analyzer of nitrogen-hydrogen mixture built on bridge throttle scheme at the beginning of the measuring range (at $C=0 \% \mathrm{~N}_{2}$ ) $-\Delta P_{I}=0$, and at the end of the measuring range (at $C=30 \% \mathrm{~N}_{2}$ ) $-\Delta P_{2}=13.766 \mathrm{kPa}$. The maximum sensitivity of the bridge scheme of analyzer is $S_{D}=459 \frac{\mathrm{Pa}}{\% \text { vol. } \mathrm{N}_{2}}$.

Therefore, using developed algorithms and programs, the authors calculated the optimal constructive parameters $B_{\text {Aopt }}, B_{B o p t}$ of bridge throttle scheme that provide optimal measuring sensitivity and the balance of bridge scheme at the beginning of the measuring range $(\Delta P=0)$.

The results of investigation of throttle schemes for building of gas-dynamic analyzer of nitrogen-hydrogen mixture with the measuring range $C=0-30 \%$ vol. $\mathrm{N}_{2}$ at $P_{\text {inp }}=200, P_{\text {out }}=110 \mathrm{kPa}, T=313 \mathrm{~K}$ are presented in table 1 . We can see that the bridge scheme of gas-dynamic analyzer of nitrogen-hydrogen mixture provides nearly twice higher measuring sensitivity (change of output signal $\Delta P=13.766 \mathrm{kPa}$ ) than the schemes built on T-L divider (change of output signal $\Delta P=6.916 \mathrm{kPa}$ ) or L-T divider (change of output signal $\Delta P=7.742 \mathrm{kPa}$ ). Thus, we can conclude that bridge throttle scheme should be applied for building the gas-dynamic analyzer of nitrogen-hydrogen mixture, 
because it has almost twice higher measuring sensitivity than the other schemes and provides balance at the beginning of the measuring range.

Table 1. The results of investigation of throttle schemes for building of gas-dynamic analyzer of nitrogen-hydrogen mixture with the measuring range $C=0-30 \%$ vol. $\mathrm{N}_{2}$ at $P_{\text {in }}=200 \mathrm{kPa}, P_{\text {out }}=110 \mathrm{kPa}, T=313 \mathrm{~K}$

\begin{tabular}{|c|c|c|c|c|}
\hline \multirow{2}{*}{ Scheme structure } & \multicolumn{2}{|c|}{ Optimal constructive parameters } & $\begin{array}{c}\text { Sensitivity } \\
S_{D}, \frac{\mathrm{Pa}}{\% \text { обN }}\end{array}$ & $\begin{array}{c}\text { Change of output signal, } \\
\Delta P=X_{\text {out } 2}-X_{\text {out }}, \mathrm{kPa}\end{array}$ \\
\cline { 2 - 3 } & $B_{\text {Aopt }}, m$ & $B_{\text {Bopt }}, m$ & 230 & 6.916 \\
\hline T-L divider & $4.6320 \cdot 10^{-6}$ & - & 258 & 7.742 \\
\hline L-T divider & - & $2.9300 \cdot 10^{-6}$ & 459 & 13.766 \\
\hline Bridge scheme & $7.3112 \cdot 10^{-6}$ & $3.8177 \cdot 10^{-6}$ & 459 \\
\hline
\end{tabular}

Taking into account the requirement of ammonia production technology and simulation results, the authors developed the principle scheme of the gas-dynamic analyzer of nitrogen-hydrogen mixture that is shown in Fig. 6.

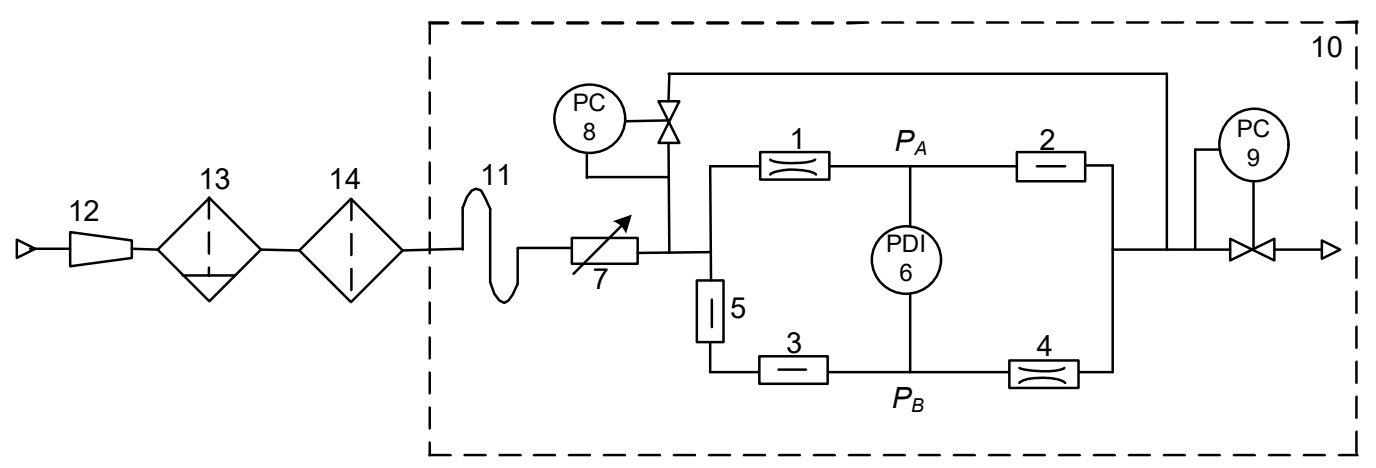

Fig. 6. Principle scheme of gas-dynamic analyzer of nitrogen-hydrogen mixture

1, 4 - turbulent throttle; 2, 3- laminar throttle; 5 - removable throttle; 7 - variable throttle;

6 - measuring device; 8, 9 - stabilizers of absolute pressure "to themselves";

10 - thermostat; 11 - heat exchanger; 12 - reducer; 13 - dehydrator; 14 - filter

The analyzer is built on the bridge throttle scheme consisting of two turbulent throttles 1 and 4 and two laminar throttles 2 and 3. The removable laminar throttle 5 is provided for the initial balancing of bridge scheme. The output diagonal of bridge scheme includes measuring device 6.

Before nitrogen-hydrogen mixture comes to the input of analyzer, it undergoes special treatment. Reducer 12 reduces the pressure of the gas mixture to a specified value $P_{i n p}=200 \mathrm{kPa}$. Gas mixture is purified from drops and water vapor in dehydrator 13 in order to improve the accuracy of measurement. Filter 14 also purifies the mixture from the solids that can block the throttle holes.

The scheme of gas-dynamic analyzer includes the pressure stabilization system that includes a variable throttle 7 and two stabilizers of absolute pressure 8 and 9 to compensate for the effects of pressure fluctuations of nitrogenhydrogen mixture. All items of gas-dynamic analyzer are placed in the thermostat 10 to compensate for the fluctuations of environment temperature. Heat exchanger 11 is installed before the bridge scheme.

The analyzer works as follows. When the composition of nitrogen-hydrogen mixture changes its physical properties density $\rho$ and viscosity $\mu$ also change and this causes a change of gas dynamic resistances of bridge scheme. As a result the output signal of bridge scheme $\Delta P=P_{A}-P_{B}$ also changes. It is measured by differential manometer 6 . Thus, each composition of the gas mixture corresponds to the certain value of the output signal $\Delta P$ of bridge throttle scheme.

The influence of uninformative parameters such as temperature and pressure of nitrogen-hydrogen mixture on output signal of analyzer is analyzed and measures for their stabilization are proposed to build the principal scheme of gas-dynamic analyzer of nitrogen-hydrogen mixture. It was found that change of temperature of nitrogen-hydrogen 
mixture for $1{ }^{\circ} \mathrm{C}$ causes the maximum change of output signal of bridge scheme at about $0.63 \%$ vol. $\mathrm{N}_{2}$, separate or simultaneous change of input pressure $P_{\text {inp }}$ or output pressure $P_{\text {out }}$ for $50 \mathrm{~Pa}$ causes the maximum change of output signal of bridge scheme at about $0.23 \%$ vol. $\mathrm{N}_{2}$. Therefore, during the stabilization of the considered parameters of analyzer at the values $T=313 \mathrm{~K}, P_{i n p}=200 \mathrm{kPa}, P_{\text {out }}=110 \mathrm{kPa}$ it is necessary to ensure the accuracy of temperature stabilization $\pm 0.2{ }^{\circ} \mathrm{C}$, and the accuracy of pressure stabilization $-50 \mathrm{~Pa}$.

The authors propose to apply the following technical means to realize the developed scheme (see Fig. 6): stabilizers of absolute pressure SAD-307 - to stabilize the pressure at the input and output of bridge scheme; pressure differential sensor Siemens Sitrans P Series DSIII - to control the output signal of bridge scheme. Glass capillary tubes [11] are proposed to use as the laminar throttles as well as clock stone type SC [12] as turbulent throttles.

The authors determined the constructive parameters of turbulent and laminar throttle elements based on the values of optimal complexes $B_{A}$ and $B_{B}$ by the selection of the ratio of dimensions at their different values. The diameters of turbulent throttles and diameters and lengths of laminar throttles were calculated using developed algorithms. Flow-rate coefficient of turbulent throttle for nitrogen-hydrogen mixture was determined from experimental data given in [12]. Calculated constructive parameters of throttle elements of bridge scheme of gasdynamic analyzer are given in table 2 .

Table 2. Constructive parameters of throttle elements of bridge scheme of gas-dynamic analyzer of nitrogen-hydrogen mixture

\begin{tabular}{|l|c|c|c|c|c|}
\hline \multirow{2}{*}{\begin{tabular}{c} 
Constructive parameters \\
\cline { 2 - 6 }
\end{tabular}} & \multicolumn{2}{|c|}{ Turbulent throttles } & \multicolumn{2}{c|}{ Laminar throttles } & $\begin{array}{c}\text { Removable } \\
\text { throttle }\end{array}$ \\
\cline { 2 - 6 } & 1 & 4 & 2 & 3 & 5 \\
\hline Diameter, $d, \mathrm{~mm}$ & 0.082 & 0.082 & 0.240 & 0.240 & 0.240 \\
\hline Length, $l, \mathrm{~mm}$ & - & - & 84.36 & 154.56 & 7 \\
\hline Flow-rate coefficient, $\alpha$ & 0.8 & 0.8 & - & - & - \\
\hline
\end{tabular}

We calculated static characteristic of gas-dynamic analyzer of nitrogen-hydrogen mixture with measuring range $\mathrm{C}=0-30 \%$ vol. $\mathrm{N}_{2}$ (see Fig. 7) taking into account optimal constructive parameters $B_{\text {Aopt }}, B_{\text {Bopt }}$ of bridge scheme. We can see that static characteristic of gas-dynamic analyzer is nearly linear and there is slight nonlinearity only at the beginning of the measuring range from 0 to $5 \%$ vol. $\mathrm{N}_{2}$.

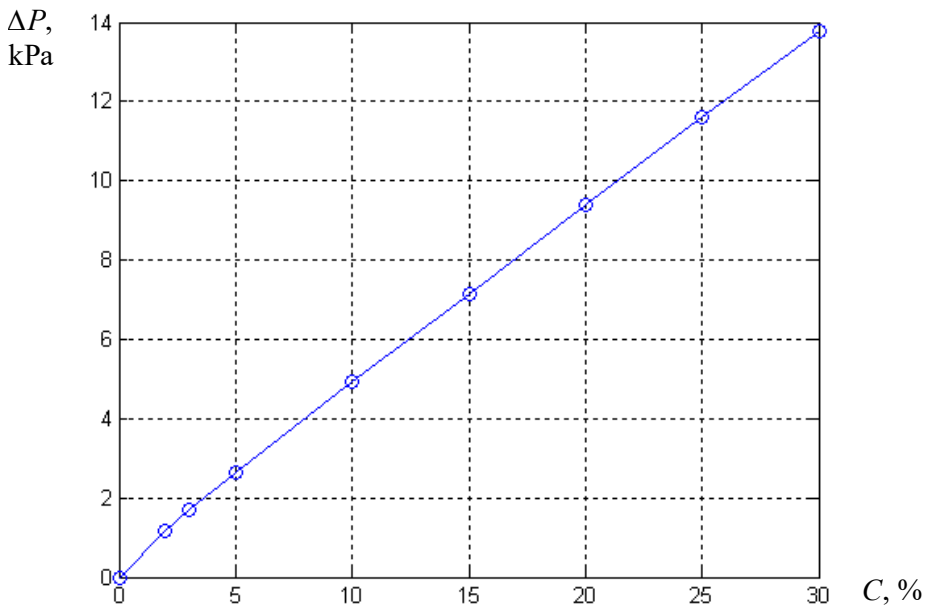

Fig. 7. Calculated static characteristic of gas-dynamic analyzer of nitrogen-hydrogen mixture

The next tasks for the investigation of developed gas-dynamic analyzer of nitrogen-hydrogen mixture are to make the decision on layout of laminar and turbulent throttles, to choose the scheme of their assembly, to develop the basic design of the device, to make experimental studies of the analyzer and to compare its calculated and 
experimental calibration characteristics. The authors analyzed different variants of composition of the analyzer in order to reduce the size of the analyzer and to reduce dead zones in its channels, to increase performance and to improve thermal stabilization condition. We recommend implementing the gas-dynamic analyzer with the output signal of pressure differential as a compact module that contains all elements.

\title{
5. Conclusion
}

Mathematical model of gas-dynamic analyzer of nitrogen-hydrogen mixture built on bridge throttle scheme using laminar-turbulent and turbulent-laminar throttle dividers is developed in the paper. It was found that the developed analyzer has twice higher sensitivity than anyone of these dividers. The authors developed a principal scheme of the gas analyzer of nitrogen-hydrogen mixture and calculated its static characteristic. There are selected the types of throttle elements, calculated their dimensions. The influence of uninformative parameters, such as temperature and pressure of nitrogen-hydrogen mixture on output signal of analyzer is analyzed and measures for their stabilization are proposed. The authors also proposed tasks for the experimental investigation of developed gasdynamic analyzer.

\section{References}

[1] V. Syemyenov, Production of ammonia, “Chemistry” Publishing House, Moscow (1985), 368 p. (in Russian)

[2] Y. Pistun, H. Leskiv, Gas-hydrodynamic measuring transducers built on complex throttle elements, "Heat power engineering. Environmental engineering. Automation." Proceedings of Lviv Polytechnic National University, No. 460, Lviv (2002), pp. 81-88. (in Ukrainian)

[3] Y. Pistun, H. Leskiv, Design and modeling of the gas-hydrodynamic measuring transducers built on bridge throttle schemes, "Heat power engineering. Environmental engineering. Automation.” Proceedings of Lviv Polytechnic National University, No. 476, Lviv (2003), pp. 18-26. (in Ukrainian)

[4] Y. Pistun, Z. Teplykh, R. Dovhanyk, High-precision throttle analyzer of binary mixture carbon dioxide - nitrogen, 9-th International Fluidics “Jablonna -82”. Conference: Institute of Biocybernetics and Biomedical Engineering - Jablonna: Poland (1982), pp. 240-248. (in Russian)

[5] Z. Teplykh, Mathematical modeling of gas-dynamic throttle bridge schemes, Journal “Automation”, No. 3, (1985), pp. 38-42 (in Russian)

[6] H. Matiko, Model of gas-dynamic transducer of composition of gas mixtures built on bridge scheme, "Heat power engineering. Environmental engineering. Automation.” Proceedings of Lviv Polytechnic National University, No. 712, Lviv (2011), pp. 146-151. (in Ukrainian)

[7] H. Matiko, H. Krykh, H. Parylovych, Gas-dynamic analyzer of nitrogen-hydrogen mixture, Materials of XIII-th International Scientific Conference "Instrument: Status and Prospects", Kyiv (2014), pp. 139-140. (in Ukrainian)

[8] Pistun, Y., Lesovoy, L. , Matiko, F., Fedoryshyn, R. (2014) Computer Aided Design of Differential Pressure Flow Meters. World Journal of Engineering and Technology, 2, 68-77. doi: 10.4236/wjet.2014.22009.

[9] Y. Pistun, Sensitivity of transducers and instruments, Journal "Metrology”, No. 1, (1983), pp. 7-12. (in Russian)

[10] Y. Pistun, Z. Teplykh, Algorithmization of calculation of gas-dynamic throttle analyzers with optimum sensitivity, Journal "Control and measurement instrumentation", No. 34, (1983), pp. 44-50. (in Russian)

[11] Z. Teplykh, Calculation of laminar pressure divider, "Thermal power systems and devices." Proceedings of Lviv Polytechnic State University, No. 273, Lviv (1993), pp. 42-44. (in Ukrainian)

[12] Y. Pistun, Z. Teplykh, I. Stasyuk, Application of time stones for measuring of low flow of gases, Journal "Measurement instrumentation", No. 11, 1983, pp. 36-38. (in Russian)

\section{Газодинамічний аналізатор складу азотоводневої суміші промислового призначення}

\author{
Галина Матіко, Свген Пістун \\ Національний університет “Львівська політехніка”, вул. С. Бандери 12, Львів, 79013, Украӥна
}

\section{Анотація}

Розроблено математичну модель газодинамічного аналізатора складу азотоводневої суміші на базі мостової дросельної схеми із ламінарно-турбулентним та турбулентно-ламінарним подільниками. 
Встановлено, що чутливість такого аналізатора є вдвічі вищою, аніж під час застосування будь-якого одного 3 цих подільників. Розроблено алгоритми для розрахунку конструктивних параметрів оптимального за чутливістю газодинамічного аналізатора складу азотоводневої суміші, виконаного на базі мостової дросельної схеми. Вибрано типи дросельних елементів мостової схеми та розраховано їх конструктивні розміри та запропоновано технічні засоби для реалізації схеми газоаналізатора. Запропоновано принципову схему газодинамічного аналізатора складу азотоводневої суміші на мостовій дросельній схемі та наведено його розрахункову статичну характеристику. Проаналізовано вплив неінформативних параметрів, а саме температури і тиску азотоводневої суміші на вихідний сигнал газодинамічного аналізатора та запропоновано заходи щодо їх стабілізації. Сформульовано завдання для експериментального дослідження розробленого газодинамічного аналізатора складу азотоводневої суміші.

Ключові слова: газодинамічний аналізатор; азотоводнева суміш; мостова дросельна схема; дросельний подільник; дросель; чутливість. 